\title{
Uexküll and contemporary biology: Some methodological reconsiderations
}

\author{
Mathias Gutmann \\ Institute of Philosophy, University of Marburg \\ Wilhelm-Röpke-Straße 6B, 35032 Marburg, Germany \\ e-mail: gutmann@staff.uni-marburg.de
}

\begin{abstract}
Philosophical anthropology and philosophical biology were both very powerful and influential movements in the German academic discussion of the early 20th century. Starting with a similar conceptual background (particularly with reference to Hans Driesch's bio-Aristotelism) they aimed at a synthetic philosophy of nature, which was supposed to include human nature into the realm of a monist description of nature itself. Within this field of biophilosophical reasoning, Jakob von Uexküll's theory of organism and his theoretical biology hold a central place. In this paper, Uexküll's theoretical biology is reconsidered as a resumption and reformulation of a theory of knowledge from a "Kantian" provenience. Its specific structure as a generalized theory of knowledge is reconstructed and the pitfalls of a biological interpretation of the condition of the possibility of knowledge are outlined. The theory of organism is reconstructed as a centrepiece of Uexküll's approach. The last section of this paper presents a proposal of engineering morphology which allows the full application of Uexküll's insights into the relativity of organismic constitution. The usefulness of functional modeling for evolutionary reconstructions on the basis of a theory of organism of uexküllian type and its relevance for biological research is evaluated.
\end{abstract}

\section{Introduction}

Jakob von Uexküll is one of the most important representatives of an "organism-centred" biology, which was developed in Germany during first decades of the 20th century. His approach resembles Kant's transcendental philosophical "metaphysics of science" in some relevant aspects. However, it is just one paradigmatic case of a variety of approaches dealing with the very fundamentals of biology, to be found 
in either "life" or in "organisms", such as H. Driesch's developmental biology, W. Roux's mechanics of development or H. Plessner's philosophical anthropology. But the task of Uexküll's theoretical biology is not only to provide a foundation for biology — at the same time it is supposed to be a fundamental extension and widening of Kant's transcendental program:

Die Aufgabe der Biologie besteht darin, die Ergebnisse der Forschungen Kants nach zwei Richtungen zu erweitern: 1. Die Rolle unseres Körpers, besonders unserer Sinnesorgane und unseres Zentralnervensystems mit zu berücksichtigen und 2. Die Beziehungen anderer Subjekte (der Tiere) zu den Gegenständen zu erforschen. (Uexküll 1973: 9)

Ironically, it is exactly this biological interpretation of Kant's program which finally leads to the methodological malformation of Uexküll's approach. My paper then attempts to achieve two goals: (1) to provide a critical revaluation of Uexküll's theory of organism, by identifying its methodological shortcomings and insufficiencies, and (2) I wish to give at least a rough sketch of a constructivist reinterpretation of this theory, which we can then fruitfully apply within the realm of biological research.

\section{Uexkülls theory of organism}

The biological elaboration of Kant's theory of knowledge refers to organisms, which veritably construct the world they live in. Space, time, meaning etc. are considered to be the products and by-products of this process of construction. So, for example, the orientation of the three canales semicirculares are connected with the three dimensions of Euclidean space (for an methodological criticism of this approach see Janich 1989). The respective senses of an organism produce a specific sense-space, which represents the structure which the organisms impose on the world by the activity of their sense organs on the one hand, and their effector-organs on the other. In accordance with its sensitive and effectorial constitution, the organisms produce Merkzeichen - signs of recognition, and Wirkzeichen - signs of effect or impact (see Uexküll 1973: 158). The result of this creative activity is an interactive relation between the organism and those aspects of the external world, of its surroundings, which are designated by the 
organism as its environment. The shift of language (from surroundings to environment) indicates the very nature of this relation. The organism is thought to be implemented into its own creation, i.e. its environment:

Schon der bloße Augenschein belehrt uns, ob wir es mit einem Luft-, Wasseroder Landtier zu tun haben. Die Flossen, die Flügel und die Füße tragen unzweideutig den Stempel ihrer Bestimmung. Je mehr der Funktionskreis auf ein eng umschriebenes Medium eingeschränkt ist, um so deutlicher kann man an den Effektoren ihre Fügung erkennen. Wir unterscheiden Saugfüße, Springfüße, Lauffüße und Kletterfüße, die uns einen ganz sicheren Anhalt geben, um das Medium der Landtiere in weitere Unterabteilungen zu zerlegen. Bei den Parasiten entdecken wir Klammerfüße, die ganz genau den Geweben ihrer Wirte, die ihnen das Medium liefern, eingefügt sind. (Uexküll 1973: 201)

This relation depends on the constitutions of the organisms itself (its Bauplan) and on the specific type of its (sensitive as well as effectorial) action. The types of these actions are summarised in the Funktionskreise, the (closed) functional circuits e.g. of medium, foodsupply, predators and reproductivity. The relationship between organisms and their respective environment can be (almost physicotheologically) described in terms of Gefüge and Gegengefüge i.e. structure and its corresponding counter-structure.

Die Tiere sind nun derart in die Natur hineingebaut, daß auch die umwelt wie ein planmäßiger Teil des Ganzen arbeitet. (Uexküll 1973: 153)

Consequently, evolution - defined as the transformation of the Bauplan, acting within the structure of its functional circuits becomes a non-gradual, and, at least in its main aspects, non-adaptive process, produced and evoked by the structure and activity of the organisms themselves; to put it in accordance with Lewontin's observation: organisms are not or not only the objects, but the subjects of their evolution as well. The worlds, the respective environments which the organisms inhabit, are specific systems of signs and representations which refer to the organismic activities and not primarily to the existing structures of the world per se. This concept, despite its undeniable merits, raises empirical as well as epistemological problems. 


\section{Empirical objections}

This becomes clear when we take a short look at the evolutionary conception. Uexküll is a prominent anti-Darwinian author, and this anti-Darwinism can be shown to be a direct consequence of his concept of organism. If organisms are well inserted into their respective umwelt (Uexküll emphasises the completeness of this relation by determining organisms as "perfect" entities) they can be considered to be in complex homoeostatic harmony with their umwelt:

Ein jeder Organismus kann nur er selbst sein. Aber in sich selbst ist er vollkommen, weil er, wie wir wissen, im Gegensatz zu unseren Gegenständen, die aus Struktur und Gefüge bestehen, nur aus Gefüge besteht. Daher darf man die grundsätzliche Behauptung aufstellen: ein jedes Lebewesen ist prinzipiell absolut vollkommen. (Uexküll 1973: 204-205)

Consequently, any shift of the inner functional contexture will lead to critical internal-external relations, unless the complete architecture itself is changed in a way that guaranties a new, evenly perfect insertion into the umwelt. From this point of view, gradual evolutionary shifts become unlikely. Only a saltationist mechanism may provide a basis for "phylogenetic" change. Uexküll borrows a mechanism of this type from developmental biology, namely the organiser-concept of Spemann, combined with Driesch's regulator-hypothesis. The ontogenetic development provides an example for abrupt organisational shifts. According to this approach, the oocytes and the zygotes of all animal phyla start as the same structure, and the differences between the single phyla are produced during development because the oocytes of the "higher" phyla do not stop their development at a special earlier stage. At each single stage of development a new organiser starts its activity. Consequently, the higher forms run through the states of those forms that stand on the lower levels of the systematic hierarchy of phyla. The development of a chick serves as an example of the activity of an organiser that starts to operate when a specific state of differentiation in the respective germ is reached:

An einem ganz bestimmten Punkt springen neue Organisatoren ein, die die bisherigen Anlagen vernichten und die im Bau begriffenen Zellen als indifferentes Ausgangsmaterial benutzen. Ein zweiter solcher Sprung ist nach der Anlage der Kiemenbögen deutlich zu erkennen. Die Kiemenbögen 
wachsen nicht zu Kiemen aus, sondern werden von mehreren Organisatoren in verschiedener Richtung umgeformt. (Uexküll 1973: 259)

From this point of view, evolution can neither be a series of gradual shifts of organisation, nor a sequence of adaptations. This anti-Darwinian approach is a consequence of the underlying theory of organism. But Uexküll has to pay a high prize for his ontogeny-oriented concept, because evolution inevitably collapses into development (Gutmann, Neumann-Held 2000).

\section{Epistemological objections}

In order to identify possible methodological objections, we should go back to the basic anticipations of Uexküll's "empirical Kantianism". When we describe organisms as the central units of environmental formation, we can infer, that within one and the same surroundings differing organisms will live in differing environments. The task of a biologist, then, is to reconstruct and understand the differing environments as the "world-images" of differing Bauplans. In order to do so, the biologist undertaking the reconstruction will have to refer to invariants of world-making, of environmental formation. To put it more epistemologically — if the semantics of the Merk-Wirk-male refers to the specific functional constitution of organisms, then we'll need at least a common syntax which allows the identification of corresponding world-aspects of differing Bauplans. This raises the most serious epistemological problems: the validity of the reconstruction of the organismic world-making and formation must not depend on the validity of this description itself. In order to avoid this type of contradiction, we have to state that the validity of our descriptions of organismic activities as a sign- and meaning-producing process is independent of the description of humans as living entities. In order to allow a self-application, Uexküll refers to a machine analogy, from which the "machine-like character" of all organisms is inferred including human organisms:

An der Untersuchung der lebenden Organismen sind drei Wissenschaften beteiligt, die Physiologie, die Psychologie und die Biologie. Alle drei geben eine verscheiden Definition des Organismus. Die Physiologie behandelt ihn als Maschine, die Psychologie als beseelte Maschine und die Biologie als 


\section{Mathias Gutmann}

autonome Maschine. Alle drei stimmen also darin überein, dem Organismus die Eigenschaften einer Maschine zuzuschreiben. (Uexküll 1973: 156)

Within the class of machines we can distinguish living from nonliving machines. Organisms, then, are machines which literally produce meaning by using signs and symbols, constructing representations of their world etc.

So far so good, but the question remains: how do we know? Let us assume that Uexküll's assumption is correct, and the constitution of environmental relationships is tightly connected with their respective Bauplan. The knowledge about all aspects of the environment is a relative knowledge about the interference between the Wirk-Gefüge of the organism and the physical, chemical or biotic aspects of its surroundings. Other organisms then appear in this constructed environment in the same way, namely as constructed aspects of the environment, created by the respective organisms itself. But all this takes place within the framework of our own description. In order to evaluate the validity, i.e. the adequacy of the description, we cannot refer to the biological knowledge we used in order to describe the type-centred, organism-environment relationships. If we did so, an infinite regress or a vicious circle would follow. We would find ourselves in a dilemma:

(1) If we knew the specific types of meanings of other non-human entities just because we reconstructed their behaviour in the environment in reference to our self-description as environmentforming entities, the validity of our knowledge about other living entities would entirely depend on the validity of our self-description. In this case we would be instantiating exactly an "as if relationship" of a Kantian style which is ruled out by premise.

(2) If, on the other hand, we presupposed that our knowledge from non-human entities refers to our own animal nature, we would either have to state that this assumption is true, because we can describe our self "as if we were" a non-human-being, or we would have to state the truth of the description referring to the type of environment formation, following Uexküll's approach. In the first case it is again an "as if relationship"; in the second we would again run into a circle or a regress. 
However, in both cases, the status of our knowledge about organisms must be based upon an "as if relationship", which contradicts our premise. As a consequence we have to state, that Uexküll provides a classical Kantian framework of "as if" descriptions of living entities in terms of organism-environment relations in the form of ontological reasoning. We can use this insight most fruitfully by radicalising exactly this Kantian point of view. In doing so we could avoid the fallacy of category which Uexküll commits by, for example, instituting his machine analogy in the way we reconstructed above. We have to transform the identity between organisms and machines into an analogy. This shift has some dramatic consequences, because now the production of meaning, the application of signs, the use of language, the creation of environment become a metaphorical description in reference to human (and not to animal) activities. Organisms have to be considered to be acting as if they were producing meaning, using language, applying signs or creating their environment. Accordingly, the reference to human action as the methodological starting-point grants the methodological validity of our descriptions of living entities behaving as if they were acting. This reconsideration of the analogy has already been used in order to provide a sound basis for the constructional-morphological reconstruction of evolutionary pathways (for a direct application see Gutmann, Gutmann 1995).

\section{Perspective of a constuctivist morphology}

Following the constructivist approach the objects of the sciences cannot be found in nature - determined and structured per se independent of our description. Considering the sciences (and a fortiori natural sciences) to be the product of human action, the objects of the sciences are the result of a "construction process". The construction of scientific objects starts within common everyday practices (Lebenswelt). This starting point is methodological, in contrast to a merely historical starting point, because it refers exclusively to practices and actions that are not constitutively based upon scientific knowledge or know-how. In order to create the very primary scientific objects we must observe a "principle of methodological order", insofar as only those concepts or notions can be used which themselves have already been introduced. The language we need in order to describe the 
resulting objects refers prescriptively towards the underlying methodological starting point; i.e. a standardized language is constructed in reference to the instructions that are creative for the underlying practice (for further reading see Janich 1997). The creative considerations that are necessary in order to construct primary scientific objects are themselves the subject matter of so called "proto" disciplines. The most important common everyday practice, which has been proven to be particularly useful for protobiological purposes, is the practice of breeding (especially of animal breeding, plant cultivation etc.). In respect to this practice we can talk about singular or collective actions, movements or qualities of animals or plants (living beings, "Lebewesen") as well-known objects, which can be described, used, manipulated and varied according to the aims of the breeder (described using the intended characteristics to be improved during breeding) and without referring to a biological theory. Those qualities, including animal action or movement, e.g. the non-scientifically described behaviour, such as the mode of motion, food-gathering etc., can include aspects of the "gestalt" of an animal, as well as the propagation of characteristics. The descriptions of these collective or singular qualities referring to cultural practices build the methodological starting point for the reconstruction of biological theories and the objects they are referring to; this reconstruction allows the determination of their respective methodological structure and status.

The resulting abstract notions are restricted to an explicable context of argument. Two languages will result: a standardized language containing all the abstractors, ideators etc. to be introduced into the scientific language $(S)$ and a language that refers to everyday language $(L)$ (see Janich 1989); $S$ and $L$ are connected by a third language that is represented by technical, physical or other kinds of non-biological knowledge. According to the purposes of protobiology, we must refer to the common everyday practices as breeding or cultivating, the keeping and utilization of living entities. In addition, for the individual steps of theory-building, several specified everyday practices, such as engineering and technical knowledge, on the one hand, and non-biological knowledge, such as physics and chemistry on the other hand, are applied as models to construct and structuralize biotic entities as objects for biological theories. The term 'structuralize' is used here to emphasize the operational definition of structures. Consequently, animals or plants don't "have" structures but they 
become "structuralized" through having models applied to them (for further reading see Gutmann 2002).

\section{The constitution of morphological objects}

The methodological starting point for the application of models, for the construction of biological objects, can be identified within the numerous cultural practices, such as using animals to carry, pull or move loads. Traditionally, horses or cattle are bred to optimize such characteristics which support the tasks required. Accordingly, these animals can be described as being used to produce force. In an abstract way, they can be described as force-generating units (Kraftaggregate). Consequently, their limbs can be described to provide optimal working conditions in order to use these forces most effectively. The fore- and hind-limbs are described as working structures, the tendons as force-transmitting structures etc.

The next step is the construction of primary morphological terms. The description of animals will invariably begin with a movement or motion of the animal (Table 1). We call the descriptions of the motions of an animal, such as "swimming", "running" "digging" etc., the bionomal options of that animal. Bionomy (a term in $S$ ) covers all descriptions of motion and movement (in $L$ ) of living beings and must not be confused with their respective description, for example, "as" locomotion (a term in $S$ ). Bionomy has to be constructed as an open list of such descriptions to avoid the problems of (mis)understanding the quantifiers "all" or "sum total" ontologically.

Bionomic descriptions of animals result, for example, in the description of animals as constructions in terms of biomechanics. The terms used to describe an animal as a construction are gained by applying the machine model. As the parts of a machine will have to work together in terms of "force closure" to ensure the mechanical continuum during work, the structures of a construction (the parts of an animal denoted "as" structures which refer to the description of the animal as a bionomal construction) will have to fit in terms of coherence. These operations, which describe an animal as a "forcegenerating unit" and its parts as "working structures" indicate a shift of language from an ordinary language (animal, working, part etc. in $L)$ to a standardized biomechanic language (structure, function, force, 
transmission etc. in $S$ ). Consequently, coherence and bionomy do not describe the characteristics of an animal in $L$ but of a construction in $S$.

Table 1. Descriptions in everyday language $(L)$ and terms in scientific language $(S)$.

$L$

list of descriptions of movement

force-closure

animal

utilization

swimming, running etc.
$S$

bionomy

coherence

construction

function

motion, locomotion

The constructive modelling procedure, which in fact shares the logical structure with constitutive metaphors (see Gutmann, Hertler 1999), can be adequately understood as the construction of a relationship between three different languages. On the one hand, there are the two languages $(S$ and $L$ ) that designate the starting point and the result of the construction. Additionally, we use knowledge and know-how of, for example, technical, physical or chemical origin during the modelling. This third language can be applied without the risk of a vicious circle because no biological knowledge (in terms of valid biological theory) is needed for the construction of the primary objects of the respective sciences and techniques.

\section{From part to structure}

Usually, an analogy is assumed to be a two-termed relation of immediate representation between a model and its intended object. In contrast to this point of view, within the constructivist approach the analogy is transformed into a three-termed "model-relation" applying non-biological, physical or technical knowledge to structuralize parts of an animal as morphological structures: e.g. the mammalian leg serving as a working structure is structuralized according to a technical lever construction. The tertium comparationis, then, is the functional rule governing the function of an idealized lever construction, 
for example in regard to its optimal geometry, the relation between the lever arm of a force and the leverage of the load, i.e. their relation to the supporting point. In general, it is possible to structuralize the "gestalt" of an animal under the given conditions as its respective bionomal construction, referring to the practice of preparation (anatomical sectioning) by applying the functional principles that are gained by modelling in the first step. The result of this model-based sectioning is the functional description of parts of the animal as the structures of the animal's construction. Applying functional models to structuralize a part of an animal, the resulting structures are the product of human operations using, for example, anatomical or histological methods. Of course, the "function" of a structure is not a "natural property" of this structure. We can call the operation, by which a part of an animal becomes functionally structuralized, the "ascription of function". When we refer to the different options of utilization, different functions of a structure and, consequently, differing structures might result, and this is an important point if they refer to the same part of the animal.

In addition, it is possible to describe even the mechanical interaction of several functionally defined structures, referring to a particular mode of their action. If muscles are described as "tension-fibresforce-generating structures" (Zugfaserelemente = TFGS), referring to the performance of the two TFGS on a single "force-transmittingstructure" (e.g., bones described "as" FTS, which may be biomechanically characterized by their flexural stiffness), an agonist and an antagonist can be distinguished. In the case of the applied models, several types of antagonism can be defined mechanically, which differ according to their geometrical arrangement, the mechanical properties of the constituting materials, their efficiency etc. By applying the hydraulic model other types of antagonism can be constructed (see W. F. Gutmann 1972; 1995). The (ant)agonist arrangements, for example, of TFGS working within a hydraulic (i.e. a fluid-filled) construction, thereby using the fluid itself as a "working substance" to generate indirect antagonism, cannot be reduced to classical lever constructions, applied as models above. 


\section{From gestalt to form}

One of the most prominent problems of traditional morphology, namely whether the "form" may be an intelligible scientific object at all, can be solved by applying the method of rational morphology I have proposed here. After the description of animals in terms of structure, function, construction, coherence, bionomy etc., the term "form" can be introduced. "Form" then is a character of the construction of two animals, structuralized successfully in reference to the same criteria of a mechanical description. If two animals are identical in reference to their construction, they share the same "form". The "identity of form" is an abstractor, introduced invariantly to the "identity of construction". To summarize, all those terms, such as structure, function etc., are gained by using, for example, engines or other machines as models to structuralize animals. Following this constructivist approach, scientific objects, constituting the "universe of discourse" of rational morphology aren't natural entities but products of human operations. Morphology itself will result as one of the numerous disciplines of biology, irreducible to any other discipline. We can summarize these operations that allow the transition from an ordinary everyday description of living entities to a construction as follows:

$$
L w \stackrel{K P}{\Rightarrow} K_{L w}
$$

The meaning of the arrow is the instruction to shift from the description of living entities towards the structuralization of constructions; $L w$ - living entity; $K$ - construction; $K P$ - principles of constructions.

Referring to the knowledge which is needed for the modelling procedure and which represents a third language in addition to the two language levels we already discerned, we can summarize the procedure as follows: 


$$
\left|\begin{array}{ccc}
T_{L w}^{1} & \operatorname{Mod}_{F_{1}} & \\
T_{L w}^{2} & \Rightarrow & S_{L w}^{1} \\
& \cdots & \\
& \cdots & \\
& \cdots & \\
& \cdots & \\
T_{L w}^{n} & \Rightarrow & S_{L w}^{n}
\end{array}\right| \Rightarrow K_{L w}
$$

Here $T$ is the specific part of the animal ( $L w$, living entity) we start with; Mod is the knowledge that is applied in terms of the specific model (e.g., the know-how of construction and the use of the lever), $F$ is the function that is modelled; $S$ is the structures resulting from the process of model-guided functional ascription (e.g., the TFGS), and $K$ is construction.

As a result of this standardization we finally gain the level of standardized scientific languages, which refers to methodologically ordered and regulated practices. The notions of constructional ("rational") morphology belong to this language level. There are several asymmetries governing the systematic relations between these language levels and the languages that belong to them respectively. The construction of biological (e.g., morphological) objects is only possible if we can refer to technical or physical knowledge. But the reverse is obviously absurd, as we do not need any biological knowledge in order to create physical objects. The same asymmetric relation can be identified between common everyday descriptions of animals and morphological descriptions or structuralizations. The result of the structuralization process is a "construction" - the rational version of the classical "bauplan" we were looking for. The structures we are dealing with now are introduced without the danger of "evolutionary implication". With the structuralization of living entities as constructions we can provide the bases of rational comparison, which we assumed to be a necessary prerequisite of systematic considerations (see Webster, Goodwin 1996). 


\section{Towards reconstructional morphology}

After the introduction of the constructions and their classification as different constructional types, the next step of our procedure is the reconstruction of possible predecessors. A reconstruction starts with the comparison of at least two constructions. We apply an explicated "transformation rule" as the tertium of the comparison. By applying such a transformation rule we are able to transform one of our constructions into the second construction with which it was to be compared. In order to provide a transformation rule of the type that is appropriate for our task here, one should bear in mind that the constructions are biomechanical structuralizations of living animals. Consequently, the transformation that shall be reconstructed must be considered as a transformation sequence that is based on biomechanical principles (presenting the transformation line of echinoderms s. fig. 1). These principles can again be borrowed from engineering. When describing animals as if they were mechanical constructions, the transformation of these constructions can be described by either optimizing them or by differentiating a given construction for different working conditions. But because animals are only treated as if they were mechanical constructions, some fundamental differences to the engineering of machines or engines must be appreciated:

In contrast to the optimization or differentiation of engines, we start the evolutionary reconstruction with the constructions of actual, existing forms and go back to those constructions that can be regarded as predecessors.

In contrast to the optimization or differentiation of engines, all the individual transformational intermediates that build a transformation line must be regarded as being "fit for work". In terms of engineering processes, the force-, form- and material-closure of the intermediates of a transformation line must be maintained during the transformation process. Additionally, the construction of a field of this type provides the abilitiy to reconstruct more than one predecessor for one given starting construction.

The antecedent constructions of a given construction must be "reinterpreted" as the biomechanic "conditions of possibility" of (formerly) living entities. This procedure, i.e. the "imagination" of living entities on the basis of the constructional description within a transformation line, can be called "reverse engineering". 


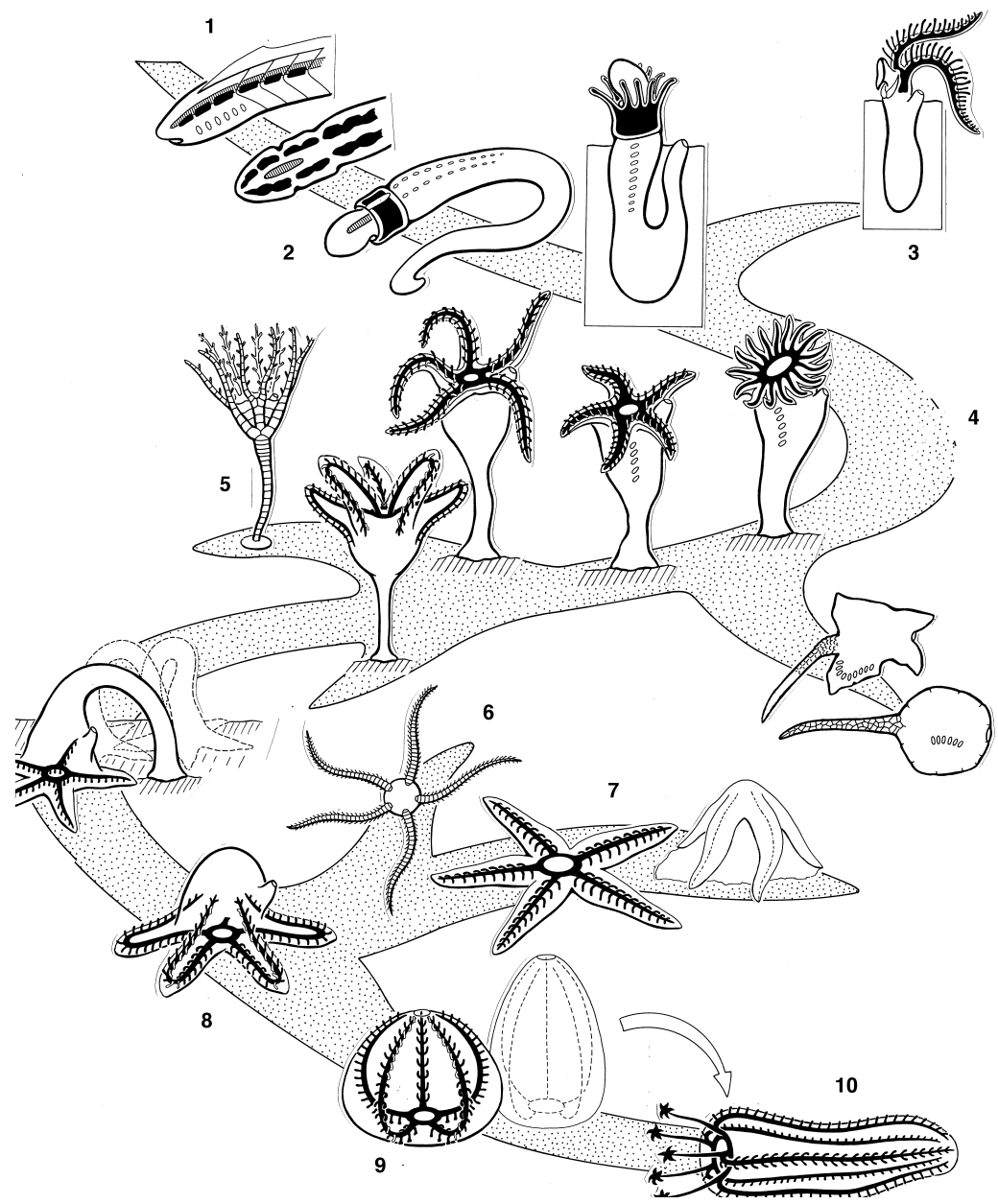

Figure 1. This drawing represents the transformation line of some fundamental echinoid bodyplans, starting with a metameric annelid-like basicconstruction; 1 ancestral Chordata, 2 ancestral Enteropneusta-like worm, 3 Pterobranchia, 4 transformation into Echinodermata construction form, 5 Crinoidea, 6 Ophiuroidea, 7 Asteroidea, 8 Eleutherozoa constructions, 9 Echinoidea, 10 Holothuria (see Gudo, Grasshoff 2002). 
For the elaboration of a reconstruction, the entire construction has to be regarded as a coherent mechanical unit. Consequently, we cannot reduce the reconstruction to the transformation of some features or characters. In complete contrast, we can identify the features which may serve as "characteristics" of evolutionary transformation only after the reconstruction was successful.

\section{Concluding remarks}

Following Uexküll's insight into the necessity of a theory of organisms, this theory can be applied fruitfully within the framework of a constructivist re-description of the machine analogy of living entities. Living entities are described and structuralized as if they were engines. The term organism then becomes a term of reflection, which provides the systematic reference of further biological descriptions e.g. in terms of evolutionary transformation. A structural deficiency of classical and neo-Darwinist theories, which was already recognised and avoided by Darwin himself, who refers to French anatomy and morphology at this point, can be avoided and at the same time the methodological locus of the resulting descriptions of living entities as organisms is identified.

\section{References}

Gudo, Manfred; Grasshoff, Michael 2002. The origin and early evolution of chordates: The "Hydroskelett-Theorie" and new insights towards a metameric ancestor. Senckenbergiana Lethaea 82(1): 325-346.

Gutmann, Mathias 2002. Aspects of crustacean evolution: The relevance of morphology for evolutionary reconstruction. Senckenbergiana Lethaea 82(1): 237-266.

Gutmann, Mathias; Gutmann, Wolfgang F. 1995. Perspektiven einer konstruktivistischen Begründung der organismischen Konstruktionslehre. In: Wallner, Fritz G.; Schimmer, Joseph (eds.), Wissenschaft und Alltag: Symposionsbeiträge zum Konstruktiven Realismus. Wien: Braumüller, 129-149.

Gutmann, Mathias; Hertler, Christine 1999. Modell und Metapher: Exemplarische Rekonstruktionen zum Hydraulikmodell und seinem Mißverständnis. In: Weingarten, Michael; Gutmann, Mathias; Engels, Eve-Marie (eds.), Jahrbuch für Geschichte und Theorie der Biologie 6. Berlin: VWB, 43-76.

Gutmann, Mathias; Neumann-Held, E. 2000. The theory of organism and the culturalist foundation of biology. Theory of Biosciences 119(3/4): 276-317. 
Gutmann, Wolfgang Friedrich 1972. Die Hydroskelett-Theorie. Aufsätze und Reden der senckenbergischen naturforschenden Gesellschaft 21: 1-91.

- 1995. Die Evolution hydraulischer Konstruktionen: Organismische Wandlung statt altdarwinistischer Anpassung. Frankfurt a. M.: Kramer.

Janich, Peter 1989: Euklids Erbe. München: Beck.

- 1997. Kleine Philosophie der Naturwissenschaften. München: Beck.

Uexküll, Jakob von 1973 [1928]. Theoretische Biologie. Frankfurt: Suhrkamp.

Webster, Gerry; Goodwin, Brian 1996. Form and Transformation: Generative and Relational Principles in Biology. Cambridge: Cambridge University Press.

\section{Юкскюлл и современная биология: некоторые методологические соображения}

Философская антропология и философская биология были обе мощными и значительными движениями в немецких академических дискуссиях начала XX века. Имея похожую концептуальную основу (в том числе имея в виду биоаристотелизм Ганса Дриша), они ставили своей целью разработку синтетической философии природы, которая должна была бы включить человеческую природу в монистическое описание самой природы. В этой биофилософской дискуссии теория Якоба фон Юкскюлла занимала центральное место. В статье теоретическая биология Юкскюлла рассматривается как продолжение и переосмысление кантовской теории познания. Pеконструктируется ее структура как общая структура знания и выделяются ловушки биологической интерпретации условий возможности знания. Теория организма рассматривается как центральная часть юкскюлловского подхода. В последней части статьи предлагается инженерная морфология, которая позволила бы полнее применить юкскюлловский подход к релятивности органистической конституции. Обосновывется полезность функционального моделирования на основе теории организма Юкскюлла и изучается ее связь с современными исследованиями в биологии.

\section{Uexküll ja kaasaegne bioloogia: Mõned metodoloogilised kaalutlused}

Nii filosoofiline antropoloogia kui filosoofiline bioloogia olid võimsad ja mõjukad liikumised saksa akadeemilistes diskussioonides 20. sajandi alul. 
Lähtudes sarnaselt kontseptuaalselt aluselt (sealhulgas silmas pidades Hans Drieschi bio-aristotelismi) seadsid nad oma eesmärgiks sünteetilise loodusfilosoofia, mis pidanuks haarama inimloomuse looduse monistlik$\mathrm{ku}$ kirjeldusse. Selles biofilosoofilises arutelus on Jakob von Uexkülli teoorial keskne koht. Käesolevas artiklis vaadeldakse Uexkülli teoreetilist bioloogiat kui kantiliku teadmiseteooria jätku ja ümbersõnastust. Rekonstrueeritakse ta eristruktuur kui teadmise üldine teooria ja tuuakse esile teadmise võimalikkuse tingimuste bioloogilise interpretatsiooni lõksud. Organismi teooriat käsitletakse kui Uexkülli lähenemise keset. Artikli viimane osa esitab insenermorfoogilise käsitluse, mis võimaldaks täielikumalt rakendada Uexkülli lähenemist organismilise konstitutsiooni relatiivsusele. Vaadeldakse funktsionaalse modelleerimise kasulikkust evolutsioonilistele rekonstruktsioonidele uexkülliliku organismiteooria alusel ja selle seotust praegusaegse bioloogilise uurimistööga. 